\title{
The Evaluation of Directly Observed Treatment Short-Course (DOTS) Implementation for TB in Hospital X
}

\author{
Ayu Prameswari* \\ *Correspondent Author: ayupramewari87@gmail.com \\ *Faculty of Medicine and Science, Universitas 'Aisyiyah Yogyakarta, Indonesia
}

\section{N D E X I N G}

Keywords:

Tuberculosis;

DOTS Strategy;

Human Resources;

Infrastructure;

Success Rate;

\begin{abstract}
A B S T R A C T
This study discusses the implementation of DOTS strategy in the provision of TB services in hospitals. DOTS is a TB treatment strategy with drug consumption supervision. The program focuses on case detection and patient treatment. This research used qualitative method with a case study design, as the data are collected using in-depth interview, observation and document review. 9 respondents are involved in this study. The achievement rate of success indicators of TB patients in the targeted hospital $\mathrm{X}$ is only on default rate $(0.8 \%)$ and failure rate $(0.3 \%)$. Meanwhile the recovery rate $(21.1 \%)$, the conversion rate $(32.7 \%)$ and the complete treatment rate $(43.5 \%)$ have not reached the target. This is because the DOTS strategy components have not been implemented optimally yet, where political commitment is inadequate, the evaluation of treatment with microscopic examination is not working properly, and the dual task of the officers results in incomplete recording. Furthermore, it is coupled with several other obstacles, such as untrained officers, unavailable special polyclinics for TB patients, and unstandardized drug (OAT) management. The conclusion are based on the results, it is concluded that the implementation of DOTS strategy in Hospital X has not been optimal yet, as it needs strong political commitment to overcome the obstacles in implementing DOTS strategy in Hospital in order to increase the scope of success rate.
\end{abstract} Penelitian ini membahas tentang pelaksanaan strategi DOTS dalam melaksanakan pelayanan TB rumah sakit. DOTS merupakan sebuah strategi pengobatan TB dengan pengawasan menelan obat. Program ini berfokus pada penemuan kasus dan penyembuhan pasien. Penelitian ini menggunakan metode kualitatif dengan rancangan studi kasus, pengumpulan data menggunakan teknik wawancara secara mendalam, observasi dan telaah dokumen. Total jumlah responden pada penelitian ini adalah 9 orang. Angka capaian indiktaor keberhasilan pasien TB di RS X yang mencapai target hanya angka default $(0,8 \%)$ dan angka gagal $(0,3 \%)$, sedangkan angka kesembuhan $(21,1 \%)$, angka konversi (32,7\%) dan angka pengobatan lengkap (43,5\%) belum mencapai target. Hal ini dikarenakan pelaksanaan komponen strategi DOTS yang belum optimal, dimana komitmen politik tidak adekuat, evaluasi pengobatan dengan pemeriksaan mikroskopis yang tidak berjalan dengan baik, dan tugas rangkap petugas yang mengakibatkan pencatatan tidak lengkap. Ditambah dengan beberapa kendala lain yaitu banyak petugas yang belum pelatihan, belum ada poli khusus pasien TB, dan pengelolaan OAT yang belum sesuai standar. Kesimpulan dari hasil tersebut bahwa pelaksanaan strategi DOTS di RS X belum optimal, dibutuhkan komitmen politik yang kuat untuk mengatasi kendala-kendala dalam pelaksanaan strategi DOTS di RS agar dapat meningkatkan cakupan angka keberhasilan.

(C) 2018 JMMR. All rights reserved

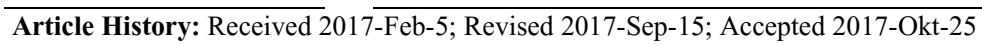

\section{INTRODUCTION}

Tuberculosis is an infectious disease caused by mycobacterium tuberculosis and is still a global health problem. ${ }^{1}$ TB is a disease that has a wide impact on the quality of life and the economic life of a person, and it can even be a life-threatening disease. ${ }^{2}$

Since 1993, WHO has declared TB as a global emergency and until recently, TB has not been successfully eradicated and has infected a third of the world's population or about 1.9 billion people. In its report, WHO estimates that there are at least 9 million new cases and 2 million people have died from TB each year. ${ }^{1}$

TB is highly infectious, as it can spread through the fluid in the airways that comes out into the air when people cough or sneeze and the air is inhaled by the surrounding people. $^{3}$ TB is the number one cause of death for class of infectious diseases in all groups of humans. Therefore, if it is not treated immediately or if the treatment is not complete, it can cause dangerous complications and even death. ${ }^{1}$ 
Southeast Asia has TB incidence rate at $38 \%$ of the total pulmonary $\mathrm{TB}$ cases worldwide and is the region with the highest TB cases. ${ }^{4} \mathrm{WHO}$ reports show that Indonesia is ranked $5^{\text {th }}$ contributor to TB in the world after India, China, Nigeria and Pakistan. At national level, TB can kill around 67,000 people every year and 183 people die every day in Indonesia. ${ }^{2}$ One of the provinces with a high rate of $\mathrm{TB}$ patients in Indonesia is Special Region of Yogyakarta (DIY) with suspect cases reaching 3855 people. DIY has not reached the established target of treatment success. TB treatment success rate in DIY is $84.2 \%$, while WHO standard is $85 \%$ and MDGs standard is $95 \%{ }^{5}$

In 1994, WHO has launched a TB control strategy, namely DOTS (Directly Observed Treatment Short-Course) strategy. The term DOTS is defined as the daily short-term drug consumption supervision conducted by the Drug Consumption Supervisor (PMO). ${ }^{6}$ According to Fitria (2015) the DOTS strategy is a way to guarantee the success of the pulmonary TB treatment program with the patient's obedience and regularity during the treatment period by supervising and controlling the treatment to the sufferers.

Indonesia started to implement the DOTS program in 1995. The program focuses on patient recovery and early case detection, and it is intended to streamline the treatment of patients and avoid any transmission of contact persons included to subclinical infections. ${ }^{1}$ In 2000 , this strategy gradually began to be developed into other health care units, they were the Community Pulmonary Health Centers (BKPM) and Hospitals. ${ }^{7}$ The TB prevalence survey results indicate that the interest of seeking TB treatment to hospital is high enough. Up to $60 \%$ of TB patients first seek for treatment to hospitals. ${ }^{7}$ Thus, involving hospitals in the DOTS strategy becomes an important and highly strategic effort, as it will make a significant contribution to the detection of new cases. ${ }^{8}$

However, the expansion of the DOTS strategy into hospitals remains a major challenge for Indonesia in controlling tuberculosis. The results of monitoring and evaluation conducted by the TB External Monitoring Mission Team in 2005 and the evaluation by the WHO and the National TB Program showed that the success rate of treatment in hospitals is still low with a high drop-out rate. This condition has the potential to create the possibility of germ resistance against Anti-Tuberculosis Drugs (MDRTB). ${ }^{9}$ In addition, in 2009 there was an assessment conducted on 18 provincial-level hospitals. The assessment data showed that only $17 \%$ of the hospitals conducted DOTS strategy optimally, $44 \%$ have moderate success rate, and $39 \%$ have low success rate. ${ }^{9}$
Hospital X has implemented DOTS strategy since October 2015. Based on preliminary study that has been done, the TB DOTS team in hospital X consists of 11 officers. 46 patients make their visits during January 2016 to June 2016. Out of these 46 patients, 9 are declared to have been cured, 27 have complete treatments, and 10 have no information at the end of the treatment. This results in inaccurate records in case recording. Therefore, it is necessary to evaluate the implementation of DOTS strategy in TB service in Hospital X.

\section{RESEARCH METHOD}

This study uses qualitative study with a case study design. This study will explore extensively the problems in the management system, the implementation of the 5 components of DOTS strategy, and the achievement of TB program success rate in hospital X.

The data processing method used is descriptive analysis. The data are collected in the form of primary and secondary data. The primary data are obtained from interviews and observations, while the secondary ones are obtained from document review. The informants from this study are all officers who joined the DOTS TB team of the hospital, which amounts to 9 respondents.

\section{RESULT AND DISCUSSION}

Table 1. Total achievement of success indicators for TB program

\begin{tabular}{lccc}
\hline \multicolumn{1}{c}{ Indicator } & Achievement & $\begin{array}{c}\text { National } \\
\text { Target }\end{array}$ & Result \\
\hline Recovery Rate & $21,1 \%$ & $\geq 85 \%$ & Unachieved \\
Default Rate & $0,8 \%$ & $\leq 10 \%$ & Achieved \\
Failure Rate & $0,3 \%$ & $\leq 4 \%$ & Achieved \\
Conversion Rate & $32,7 \%$ & $\geq 80 \%$ & Unachieved \\
Complete & & & \\
Treatment Rate & $43,5 \%$ & $\geq 85 \%$ & Unachieved \\
\hline
\end{tabular}

Based on the table, it is found that the DOTS strategy has not been conducted optimally yet in Hospital X. From the program success indicators, only the default and failure rates could achieve the targets. Meanwhile the recovery, conversion and complete treatment rates have not been achieved. 
The default rate in Hospital $\mathrm{X}$ is 7 patients $(0.8 \%)$. This is a success since WHO has set that the target default rate should not be more than $10 \%$. The success of this achievement is because the officers always monitor the patient's control schedule, if the patient is absent the officers will call the patient. This result is in line with Saad \& Chandra who find that DOTS team of RSUP Arifin Achmad will call the patient and supervisor if the patient does not come for treatment at the appointed time. The role of the officers who supervise the patient's treatment schedule by phone is very effective in monitoring the regularity of the patient's treatment, so that it can suppress the default rate patients in Hospital X. ${ }^{11}$

In addition, the achievement of the default rate is also due to the cooperation between the hospital officers and the Community Health Center (Puskesmas) officers and the Health Office officers which have been done quite well. Based on the results of interview, it is found that if a patient cannot be contacted, the officer will contact the TB Community Health Center officers via WhatsApp (WA) Messenger application, and if the patient cannot be found, the officers will assign the Health Office Officers to track the patient. Improving the cooperation between Hospital, Community Health Center, and Health Office Officers is one way that can reduce the default rate of patients so that the patient's tracking process becomes easier. As revealed by Trisna \& Ilyas, a good cooperation between programs is expected to have success on tuberculosis handling program with increasing coverage of success indicator. ${ }^{12}$

Furthermore, another indicator which successfully reaches the target is the failure rate, i.e. only 3 patients $(0,3 \%)$. This is a success since the national target for the failure rate for patients should not be more than $4 \%$. This rate is obtained from patients who do not continue treatment due to disease complications, thus their Anti Tuberculosis Drugs (OAT) is terminated. As found in the study conducted by Bagiada \& Putri, the failure rate of TB patients in the treatment is caused by many factors including drugs, disease, and the patients themselves. ${ }^{13}$ The disease factor is usually caused by overly broad lesions, the presence of other diseases that follow and the presence of immunological disorders.

In addition to the above factors, in the researcher's opinion, both indicator achievements are also caused by the Drug Consumption Supervisor (PMO). In line with the study conducted by Silvani, one of the contributors to the success of programs for pulmonary TB treatment is Drug Consumption Supervisor (PMO). ${ }^{14}$ Results of other studies also suggest that the a good supervisor will have some effect on the increased adherence to treatment, thus the patients are highly likely to consume drugs regularly so as to encourage the recovery of patients with pulmonary TB or treatment success. ${ }^{15}$

Based on the interviews that have been done, the hospital officers determine the supervisor based on several criteria, i.e. the supervisor is a family member who lives in the same house with the patient and is able to supervise the patient to consume the medicine. Also in line with the research conducted by Adhista \& Santi, most of the patients in Tanah Kalikedinding Community Health Center have supervisor, where all of these supervisors are the family member of the patients and mostly are the husband or wife of the patients. ${ }^{16}$ From this result, the researcher argues that the selection of family member to be a supervisor is quite effective, hence the default and failure rates in this hospital do not exceed the predetermined target. According to Nurhayati, the success of TB treatment with DOTS strategy in patients in this study is supported by some supervisors who have a family relationship with patients. ${ }^{17}$ Furthermore, together with the Drug Consumption supervisor (PMO), the role of the officers in monitoring the regularity of TB patient's treatment becomes easier, because the officers can contact their family members if they are absent, therefore the default and failure rates are low. This study is in line with Elangovan, who discloses that mobile phone is used for tracking patients when they move or provide wrong address, as sometimes, the healthcare officers advise family members of the patients over the phone and provide education about prevention and the importance of treatment. ${ }^{18}$

By involving their family members as supervisors, patients get support in undergoing the treatment and it can certainly support the success of the program. Octavianus, finds that family support has a significant relationship with the drop-out incidence as evidenced by the calculation of chi square obtained by the value of continuity correction of 52.027 and the $\mathrm{p}$ value $=0.00001(\mathrm{p}<0.05) .{ }^{19}$

Moreover, according to Silvani, the more the supervisor supports the more likely the treatment of tuberculosis to be successful. ${ }^{6}$ Therefore, the possible effort is to increase the role of supervisor for the successful treatment of pulmonary tuberculosis through counseling to the family as the closest supervisor to patients by providing information about diseases, symptoms and treatment of pulmonary tuberculosis. However, this study obtains different result. The counseling process does not go well, where officers do not do counseling to the family members of patients, as the counseling is only given to the patients. 
Based on these results, the researcher believes that counseling does not affect the success of the achievement of the default and failure rates in hospital X. This result is consistent with the research conducted by Ramdaniati \& Hassan, who find that there is no influence of counseling and obedience of TB patients on the treatment with $\mathrm{p}$ value $>0.05$. However, there is a need to conduct further study on these results because it is also important to provide information to patients and family members for better treatment and more effective treatment process. ${ }^{20}$ As suggested by Malau \& Rochadi's study, healthcare officers need to improve their counseling to improve understanding and motivation for the patients, so that the patients and their family members get sufficient comprehension on $T B$, the prevention and consequence of irregular treatment, so as to improve the patient's compliance to come for treatment. ${ }^{21}$

Furthermore, there will be a discussion on the indicators that have not been achieved, namely the recovery, conversion and complete treatment rates. From the review of documents, the recovery rate of TB patients in hospital $\mathrm{X}$ is 11 patients $(21.1 \%)$. This rate is far from the national target which is set at $85 \%$. This low rate is because patients who have successfully completed the treatment period do not perform sputum examination. As indicated in the manual of tuberculosis control, it is explained that the recovery rate is obtained in patients who have completed the treatment period and is proven by the results of sputum examination with negative result. ${ }^{1}$

Based on the review of documents, it is found that from 92 patients who have completed the treatment period, $84(91,3 \%)$ of them do not perform evaluation at the end of treatment. According to Isbaniah, examination and evaluation of microscopic examination shall be performed before the treatment starts, after 2 months of treatment, and at the end of treatment, as this also applies to radiological examination. ${ }^{22}$ Furthermore, according to Amin \& Bahar, sputum examination should still be performed for having a control on the patients who have finished treatment or on the patients who have recovered, because it is an anticipation for possible silent bacterial shedding or positive BTA sputum without any complaints. ${ }^{23}$

Another indicator which has not been achieved is recovery rate. The low recovery rate is caused by the low conversion rate of TB patients in Hospital X. As revealed by Supardi, et al, the high conversion rate will be followed by a high recovery rate, vice versa, if the conversion rate is low the recovery rate will also be low. ${ }^{24}$ In addition, Amaliah, argue that the low conversion rate in the intensive treatment is a matter to note, because it is related to the treatment process of TB patients which will have an impact on the success of treatment. ${ }^{25}$

In this study, the conversion rate obtained is 17 patients $(32.7 \%)$. Similar to the recovery rate, the low conversion rate is because the patients do not have a repeat sputum examination at the end of the intensive phase of treatment. Based on the data obtained from 92 patients, 71 patients $(77.1 \%)$ do not have themselves re-examined. This is because many patients find it difficult to spit their sputum after receiving treatment. This is in line with the research conducted by Mansur, who finds that some patients do not know how to accommodate the correct sputum and it is often the case that the patients have trouble in spitting out, resulting in possible errors to occur in reading the results of the examination. ${ }^{26}$ In turn this will inhibit the treatment process.

In addition, officers also admit that most of the patients think they fully recovered, thus they do not think they need re-examination and come back for treatment. In line with the study conducted by Firdaufan, et al, one of the inhibiting factors that affect the success of treatment is that the patients decide to cease the treatment they receive because they have felt better. ${ }^{27}$ The study conducted by Slama, et al, also finds the same, i.e. the main reason for patients to drop-out the treatment is that they feel recovered, hence they drop-out the treatment. ${ }^{28}$

In this case, the factor which influences the recovery and conversion rates in Hospital $\mathrm{X}$ is the evaluation of treatment with microscopic sputum examination that has not been optimized. According Nurmadya, et al, the poor implementation of an examination will increase the percentage of respondents who have unsuccessful treatment, as the statistical test results obtain significant differences with $\mathrm{p}=0,05{ }^{29}$

In the researcher's opinion, it is necessary to evaluate the implementation of microscopic examination in this hospital laboratory, because based on the data obtained from the process of case finding, many TB patients are not diagnosed with sputum examination, as indicated by the fact that 43 or $36.4 \%$ of the 118 patients receive micrsocopic examination as well as investigation in the procees of TB diagnosis. This is certainly not in accordance with the applicable standard procedures. As has been widely known, the diagnosis performed on TB patients should include microscopic sputum examination. According to Kurniawan, et al, sputum examination is important because the diagnosis of pulmonary tuberculosis can be established if positive smear results are obtained. ${ }^{30}$ 
In addition to sputum examination, there should also be an evaluation of the success of treatment provided.

The unmaximized implementation of this microscopic examination may be caused by the absence of evaluation of hospital laboratory unit. Based on the interview, the laboratory of hospital X has never conducted an evaluation of external stabilization and quality improvement. This may be one of the factors of nonmaximal micrsocopic examination at the stage of treatment evaluation. Based on the guidelines for tuberculosis prevention in 2014, the stabilization of TB laboratory service quality is a continuously arranged system to improve the reliability and efficiency of the examination as a diagnostic tool and to monitor the results of treatment, as this activity is necessary for the diagnosis of TB disease which can be accounted for its quality. ${ }^{13}$

The evaluation has not been implemented in the hospital laboratory unit because of the lack of supervision from the Health Office to the hospital. According to the officers, the evaluation is only done when the officer performs the data validation to the Health Department quarterly, as the Health Office never make a visit to the hospital. They do so only at the beginning of formation of the program and for the purpose of accreditation, rather than to supervise the laboratory unit. According to Zou, et $\mathrm{al}$, in order to improve cooperation between hospitals and TB program, there is a need of alignment of interests of both parties, improvement on staff training, and improvement on supervision of TB control programs in hospitals, so that the success of the program can be achieved. $^{31}$ Moreover, the research conducted by Rahmawati \& Budiono, finds that the relationship between supervision by the Health Office and achievement of succes rate of pulmonary TB in Sragen regency has a $\mathrm{P}$ value of $0.041(0.041>0.05){ }^{32}$

Furthermore, the indicator that has not been successfully achieved is the complete treatment rate. Based on the review of documents, the total complete treatment rate of $\mathrm{TB}$ patients in Hospital $\mathrm{X}$ is 40 patients $(43.5 \%)$. This rate is higher than the recovery rate. This is because of the officers who always monitor the treatment schedule by calling the patients if they do not come on a predetermined schedule, so that the patients can complete the treatment process regularly for 6 or 9 months. According to Saad \& Chandra, supervision and attention provided by the healthcare officers and family members are one of the factors that affect patient compliance in undergoing treatment that takes a long term period. ${ }^{11}$
However, although the complete treatment rate is higher than the recovery rate, this rate is still far from the national target of $85 \%$. In the researcher's opinion, this is due to incomplete data recording on TB patients. Based on the results, the data recorded on 31 patients $(33.7 \%)$ are incomplete. The completeness of recording is important, considering that the function of recording and reporting is to help monitor the program and to supervise the process of treatment on TB patients. According to Rahmawati \& Budiono, recording and reporting systems are very useful in the process of evaluating TB programs as an anticipation when some patients are lost to follow-up the treatment and a help to reduce drop-out rate in TB patients. ${ }^{32}$

Based on the observations conducted, the incomplete data recording of TB patients due to the recording officers have double duties, as nurses in the internal and neurological polyclinics at the same time. In addition, the officers are also responsible for taking non-logistical needs. This result is in line with the research conducted by Saad \& Chandra, which finds that the recording and reporting do not run optimally due to the recording officers have double duties. $^{11}$

In addition, the recording nurses have additional duties in the management of anti-tuberculosis drugs (OAT) in the hospital. Based on the results, hospital $\mathrm{X}$ does not have a pharmacist who administers drugs (OAT) and there is no record and report of drug management. The number of tasks that must be done by this recording and reporting officers can disrupt their performance in carrying out their duties, leading to less optimal process of recording on TB patients. According to Trisna \& Ilyas, the high workload of nurses in Community Health Center in the management of $\mathrm{TB}$ is one of the factors that can decrease morale and give effect to the nurses' decreased performances. ${ }^{12}$

From the above results, it can be concluded that the recording officers have so many duties as the nurses of TB service, although the hospital has a DOTS team. This shows that the cooperation in the TB DOTS team in the hospital is not effective. The purpose of team building is to build cooperation among DOTS team members who are expected to achieve the success of the implementation of TB program in the hospital. Based on the interviews, the TB DOTS team in the hospital did not conduct regular meetings. During the formation of the team, the members only met two times at the time of team buliding and when the hospital will be accredited. These results indicate that the internal network implementation is not maximal, resulting in a workload that only relies on one officer and does not build a good teamwork. In line with the study 
conducted by Saad \& Chandra, the internal network of the DOTS team has not run as desired, due to lack of coordination and socialization. ${ }^{11}$ According to the Ministerial Decree of Health (2010), in the implementation of the DOTS team program of a hospital, there must be regular meetings held to discuss all the findings related to the implementation of services to $\mathrm{TB}$ patients in the hospital.

The lack of cooperation between DOTS team members is probably due to lack of socialization and attention from the hospital management so that the division of tasks becomes unevenly distributed and relies on the recording officers. This is certainly related to the commitment of the hospital to the implementation of the program. As found from the results obtained, the hospital does not supervise the implementation of TB program, whereas the function of supervision is to evaluate the course of program, identify the obstacles and plan a followup to solve problems encountered in the implementation of the program. This result is in line with the research conducted by Suarni, et al, which finds that one of the factors influencing the less maximum implementation of DOTS in RSMP is the monitoring and evaluation of RSMP internally that has not been run yet. ${ }^{33}$ In contrast to the results of study conducted by Aditama, the supervision is carried out by the head of the Community Health Center in the form of regular monthly meetings to check the progress and obstacles of each program including the TB handling program. ${ }^{34}$

If the supervision activities are carried out regularly, the workload problems can certainly be immediately solved. By involving hospital management, it will be possible to evaluate the workload of the recording officers and hence can be distributed to the nurses equally. Trisna \& Ilyas, state that the ability of the heads of Community Health Center is very important in the distribution of tasks, as all personnel are given proportional tasks and responsibilities that must be done so that the tasks are evenly distributed, which requires a good cross-program cooperation. ${ }^{12}$ When this is effectively done, the implementation of P2TB program activities can succeed with the achieved indicators, especially for the recovery rate of the patients.

Furthermore, in addition to not conducting supervision, the hospital did not receive reports of $\mathrm{TB}$ services from the officers either. The officers only report it to the Health Office. This shows that the involvement of the hospital as the program organizer is less optimal. In the guidelines for tuberculosis control (2010), there sholud be reports and evaluation results of the implementation of internal networks and there should be a follow-up plan of evaluation results. This result is not much different from the result of study conducted by Saad \& Chandra which finds that DOTS team of RSUD Arifin Achmad has submitted report to the hospital quarterly, yet it is never followed up. ${ }^{11}$

It is difficult to have optimal implementation of the program if the participants do not have a strong commitment, non-optimal internal network, and the absence of evaluatioan and follow-up actions from hospital management line which causes the indicators failing to meet the targets. As expressed by Sumantyo and Probandari, strong individual commitments from every healthcare professional, as well as relevant policies in Hospital and National TB Programs are urgently needed to strengthen the implementation of DOTS in hospital. ${ }^{35}$ This opinion is also supported by Harries, who suggests that poltical commitment is needed to develop, implement and supervise tuberculosis service standards in order to achieve success. $^{36}$

In addition to the above problems, there are still some obstacles in the implementation of the DOTS strategy in Hospital X, namely the unavailability of special room for $\mathrm{TB}$ patients and the service being still incorporated with pulmonary disease patients. However, these are not great obstacles because the service to TB patients can still be done quite well. This confirms the study conducted by Sugihantoro \& Rustamaji, which finds that the limitation of TB services in RSD DR. Soebandi is the unavailability of special polyclinic for service to TB patients. ${ }^{37}$

Another obstacle is the lack of trained personnel incorporated in the DOTS team. Based on the interviews, the reason for many officers having not been included into the training is the limited funds and absence of response from the Health Office. These results are in line with the study conducted by Nugraini, et al, which finds that the municipal and provincial health offices have not conducted pulmonary TB training due to limited funds, as they only conduct refreshing activities every month so that the knowledge, attitudes and skills of officers in finding new cases are still limited and CDR has not acvieved the target yet. ${ }^{38}$ Also, the officers said that the Health Office prioritizes the Community Health Center officers for training than the hospital officers. This result is supported by the study conducted by Aditama, et al, which finds that TB clinic officers who have not participated in training are only about $3.35 \%$, much more lesser than the hospital officers and doctors who have not been included into training of about $57.14 \% .{ }^{34}$ This will require an evaluation 
of the policies by the program stakeholders, because with the provision of training, the officers can run TB services in accordance with the standards, in addition to training on the reduction of possibility of errors in carrying out tasks.

Furthermore, in relation to the policy, in addition to the uneven training, the availability of anti-tuberculosis drugs (OAT) is also sometimes not on demand in the hospital. Based on the interview, the Health Office prioritize the need of medicines at the Community Health Centers compared to hospitals. This result is the same as the result of study conducted by Sugihantoro \& Rustamaji, that there is a difference between the amount of planned and provided drugs. ${ }^{37}$ This is because the Health Office prioritize OAT for the Community Health Center as the it constituted a prioritized agency in TB control. These obstacles, which are not followed up by the program stakeholders, make the coverage of TB treatment success rate difficult to achieve. This requires an evaluation and immediate improvement so that this program can help handling the TB patients at national level in the future.

\section{CONCLUSIONS}

The success indicators that can achieve the national targets are the default and failure rates, due to the role of the implementing officers in monitoring the patient's control schedule, the presence of drugs consumption supervisor (PMO) in assisting the officers in supervising the patients, as well as the external networks that assist in patient tracking. The indicators that have not yet achieved the targets are the recovery, conversion and complete treatment rates. This is due to microscopic examinations that are not up to standard and the high workload of the implementing officers. Both factors are caused by lack of political commitment where there is no evaluation and improvement of the program, so that has impacts on the achievement of those three success indicators. There are other factors that also affect the success of the program, namely the unavalability of special rooms for TB patients, the high number of untrained officers, and government policies.

\section{ACKNOWLEDGMENT}

Thanks to the team of hospital X, especially the DOTS TB team who have been a lot of help in this research process, so that this research can run well and maximally. I would also like to extend my gratitude to the campus members and lecturers in this study who have provided much input and assistance in the process of preparation of this research.

\section{REFERENCE}

1. Indonesia, K. K. R., \& Penyakit, D. J. P. (2014). Pedoman Nasional Pengendalian Tuberkulosis. Kementerian Kesehatan Republik Indonesia, 2(1-3), 1-35

2. Mansur, M. (2015). Analisis Penatalaksanaan Program Penanggulangan Tuberkulosis Paru dengan Strategi DOTS di Puskesmas Desa Lalang Kecamatan Medan Sunggal Tahun 2015. FKM USU. Medan.

3. Marwati, L., \& Nugroho, Y. S. (2016). Aplikasi Diagnosa TBC Menggunakan Metode Naive Bayes. (Doctoral Dissertation, Universitas Muhammadiyah Surakarta).

4. Kementerian Kesehatan R. I. (2011). Pedoman Nasional Penanggulangan Tiberkulosis. Jakarta; Menkes RI.

5. Dinas Kesehatan Kota Yogyakarta. (2011). Profil Dinas Kesehatan Kota Yogyakarta Tahun 2011. Yogyakarta

6. Isbaniah, F. (2011). Pedoman Diagnosis dan Penatalaksanaan Tuberkulosis di Indonesia. Jakarta: Perhimpunan Dokter Paru Indonesia.

7. Ditjen, D. K. R. (2007). Pedoman Penerapan Dots di Rumah Sakit.

8. Fitria, D. (2015). Analisa Kinerja Petugas TB (Tuberculosis) di Rumah Sakit yang Telah Dilatih Program HDL (Hospital DOTs Lengkage) di Kota Medan (Master' s Thesis. USU).

9. Indonesia, K. K. R. (2010). Laporan Riset Kesehatan Dasar Tahun 2010. Jakarta: Badan Penelitian dan Pengembangan Kesehatan.

10. Muniroh, H., \& Aisah, S. (2013). Faktor-Faktor yang Berhubungan dengan Kesembuhan Penyakit Tuberkulosis (TBC) Paru di Wilayah Kerja Puskesmas Mangkang Semarang Barat. Jurnal Keperawatan Komunitas, 1(1)

11. Saad, A., \& Chandra, F. (2014). Penilaian Keberhasilan Program TB DOTS Berdasarkan Angka Keberhasilan Pengobatan dan Angka Konversi di RSUD Arifin Achmad Provinsi Riau Periode Januari 2008Desember 2012. Jurnal Online Mahasiswa Fakultas Kedokteran Universitas Riau, 1(2), 1-14.

12. Trisna, E., \& Ilyas, H. (2017). Analisa Faktor-faktor yang Berhubungan dengan Kinerja Perawat dalam Penatalaksanaan Tuberkulosis. Jurnal Keperawatan, 9(1), 71-78. 
13. Bagiada, I., \& Putri Primasari, N. L. (2010). Faktorfaktor yang Mempengaruhi Tingkat Ketidakpatuhan Penderita Tuberkulosis dalam Berobat di Poliklinik DOTS RSUP Sanglah Denpasar. Journal of Internal Medicine. 11(3).

14. Silvani, H. (2016). Hubungan Peran Aktif Keluarga Sebagai Pengawas Minum Obat (PMO) dengan Angka Kekambuhan TB Paru di Ruang Seruni RSUD Abdul Wahab Sjahranie Samarinda. Jurnal Ilmu Kesehatan, 4(2), 66-74

15. Muniroh, H., \& Aisah, S. (2013). Faktor-Faktor yang Berhubungan dengan Kesembuhan Penyakit Tuberkulosis (TBC) Paru di Wilayah Kerja Puskesmas Mangkang Semarang Barat. Jurnal Keperawatan Komunitas, 1(1)

16. Adhista Eka, N., \& Santi, M. (2014). Evaluasi Program Pengendalian Tuberkulosis Paru dengan Strategi DOTS di Puskesmas Tanah Kalikedinding Surabaya. Jurnal Berkala Epidemiologi, 2(2), 251-262

17. Nurhayati, J. (2014). Hubungan Kinerja Pengawas Menelan Obat terhadap Keberhasilan Pengobatan TB Paru dengan DOTS di RSUP Dr. Kariadi Semarang. MEDICA HOSPITALIA-JOURNAL OF CLINICAL MEDICINE, 2(1).

18. Elangovan, R., \& Arulchelvan, S. (2013). A Study on The Role of Mobile Phone Communcation in Tuberculosis DOTS Treatment. Indian journal of community medicine: official publication of Indian Association of Preventive \& Social Medicine, 38(4), 229.

19. Octavianus, L. (2012). Analisis Faktor-faktor yang Berhubungan dengan Kejadian Drop Out Penderita TB Paru di Puskesmas Kota Sorong Tahun 2011. (Doctoral Dissertation, UNIVERSITAS DIPONEGORO).

20. Ramdaniati, S. N., \& Hassan , A. (2017). Faktor-faktor yang Berhubungan dengan Tingkat Kepatuhan Pengobatan Pasien TB Paru Terkonfirmasi Bakteriologis di Puskesmas Unyur dan Puskesmas Kilasah Kota Serang Tahun 2016. Scientum: Jurnal Ilmiah Dewan Riset Daerah Banten, 6(1), 59-74.

21. Malau, D., \& Rochadi, R. K. (2015). Hubungan Komunikasi Interpersonal Petugas Kesehatan terhadap Kepatuhan Pasien Menjalani Pengobatan TB Paru di Puskesmas Sunggal Medan Tahun 2014. Kebijakan, Promosi Kesehatan dan Biostatistik, 1(2).

22. Isbaniah, F. (2011). Pedoman Diagnosis dan Penatalaksanaan Tuberkulosis di Indonesia. Jakarta: Perhimpunan Dokter Paru Indonesia.
23. Amin, Z., \& Bahar, A. (2010). Buku Ajar Ilmu Penyakit dalam Jilid III Edisi V. Jakarta: Internal Publishing.

24. Supardi, U. K., Thaha, I. L. M., \& Rismayanti, R. (2016). Determinan Sosial dan Keteraturan Berobat terhadap Perubahan Konversi Pasien Tuberkulosis Paru. Media Kesehatan Masyarakat Indonesia, 10(3), 125-130.

25. Amaliah, R. (2012). Faktor-faktor yang Berhubungan dengan Kegagalan Konversi Penderita TB Paru BTA Positif Pengobatan Fase Intensif di Kabupaten Bekasi Tahun 2010. Depok. Universitas Indonesia.

26. Mansur, M. (2015). Analisis Penatalaksanaan Program Penanggulangan Tuberkulosis Paru dengan Strategi DOTS di Puskesmas Desa Lalang Kecamatan Medan Sunggal Tahun 2015. FKM USU. Medan.

27. Firdaufan, Santoso, Hartono, R., Hendratno, Sumardiyono, Sutisna, E., \& Syahril, M. (2009). Evaluasi Program Pengendalian Tuberkulosis dengan Strategi DOTS di Eks Karesidenan Surakarta. Jurnal Kedokteran Indonesia, 1(2).

28. Slama, K., Tachfaouti, N., Obtel, M., \& Nejjari, C. (2013). Factors Associated with Treatment Default by Tuberculosis Patients in Fez, Marocco.

29. Nurmadya, N., Medison, I., \& Bachtiar, H. (2015). Hubungan Pelaksanaan Strategi Directly Observed Treatment Short-Course dengan Hasil Pengobatan Tuberkulosis Paru Puskesmas Padang Pasir Kota Padang 2011-2013. Jurnal Kesehatan Andalas, 4(1).

30. Kurniawan, N., Rahmalia, S., \& Indriati, G. (2015). Faktor-faktor yang Mempengaruhi Keberhasilan Pengobatan Tuberkulosis Paru. JOM, 2(1).

31. Zou, G., King, R., Walley, J., Yin, J., Sun, Q., \& Wei, X. (2015). Barriers to Hospital and Tuberculosis Programme Collaboration in China: Context Matters. Global Health Action, 8(1), 27067.

32. Rahmawati, D., \& Budiono, I. (2015). Faktor Pelayanan Kesehatan yang Berhubungan dengan Keberhasilan Pengobatan (Success Rate) TB Paru di Kabupaten Sragen. Unnes Journal of Public Helath, 4(4).

33. Suarni, E., Rosita, Y., \& Irawanda, V. (2013). Implementasi Terapi DOTS (Directly Observed Treatment Short-Course) pada TB Paru di RS Muhammadiyah Palembang. Syifa' MEDIKA: Jurnal Kedokteran dan Kesehatan, 3(2), 128-136.

34. Aditama, W., Zulfikar, Z., \& Baning, R. (2013). Evaluasi program Penanggulangan Tuberkulosis Paru di Kabupaten Boyolali. Kesmas: National Public Health Journal, 7(6), 243-250. 
35. Sumantyo, H., \& Probandari, A. (2013). Faktor-Faktor Manajerial Pelayanan TB dan Tingkat Keteraturan Berobat Pasien TB di RSUD Muntilan. (Doctoral Dissertation, Universitas Gadjah Mada).

36. Harries, A. D., Jahn, A., Zachariah, R., \& Enarson, D. (2008). Adapting DOTS Framework for Tuberculosis Control to the Management of Non-Communicable Diseases In Sub-Saharan Africa. PLoS Medicine, 5(6), el24. Http: //doi.org/10.1371/journal.pmed.0050124.

37. Sugihantoro, H., \& Rustamaji, M.K. (2012). Implementasi Strategi DOTS (Directly Observed Treatment Short-Course) di RSD DR. Soebandi Kabupaten Jember Provinsi Jawa Timur Tahun 2010 (Doctoral Dissertation, [Yogyakarta]: Universitas Gadjah Mada)

38. Nugraini, K. E., Cahyati, w. H., \& Farida, E. (2015). Evaluasi Input Capaian Case Datection Rate (CDR) TB Paru dalam Program Penanggulangan Penyakit TN Paru (P2TB) Puskesmas Tahun 2012 (Studi Kualitatif di Kota Semarang). Unnes Journal of Public Health, 4(2). 